\title{
PENGARUH CAPITAL ADEQUACY RATIO (CAR), LOAN TO DEPOSIT RATIO (LDR), DAN NET INTEREST MARGIN (NIM) TERHADAP RETURN ON ASSETS (ROA) PADA BANK UMUM SWASTA NASIONAL DEVISA YANG TERDAFTAR DI BURSA EFEK INDONESIA TAHUN 2015-2017
}

\author{
Moch. Irfan ${ }^{1}$, I Wayan Suwendra², I Nyoman Sujana ${ }^{3}$ \\ Program Studi Pendidikan Ekonomi, Fakultas Ekonomi \\ Universitas Pendidikan Ganesha \\ Singaraja, Indonesia

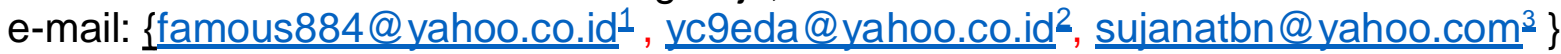

\begin{abstract}
Abstrak
Penelitian ini bertujuan untuk mengetahui pengaruh (CAR) terhadap (ROA), untuk mengetahui pengaruh (LDR) terhadap (ROA), untuk mengetahui pengaruh (NIM) terhadap (ROA), dan untuk mengetahui pengaruh (CAR), (LDR), dan (NIM) terhadap (ROA) pada bank umum swasta nasional devisa yang terdaftar di Bursa Efek Indonesia 2015-2017. Penelitian ini menggunakan rancangan penelitian kuantitatif kausal. Subjek penelitian ini adalah Bank Umum Swastra Nasional Devisa periode 2015-2017. Objek dalam penelitian ini adalah laporan keuangan yang terdiri dari ratio-ratio antara lain CAR, LDR, NIM dan ROA tahun 2015-2017. Data yang diperoleh dikumpulkan dengan menggunakan metode dokumentasi. Hasil penelitian ini adalah terdapat pengaruh CAR terhadap ROA. Hal ini dapat dilihat dari hasil yang menunjukkan nilai $t$ sebesar 2,108 dengan $p$-value $=0,040<\alpha=0,05$. Terdapat pengaruh LDR terhadap ROA. Hal ini dapat dilihat dari hasil yang menunjukkan nilai t sebesar 2,829 dengan $p$-value $=0,000<\alpha=$ 0,05 . Terdapat pengaruh NIM terhadap ROA. Hal ini dapat dilihat dari hasil yang menunjukkan nilai t 2,200 dengan $p$-value $=0,032<\alpha=0,05$. Terdapat pengaruh CAR, LDR, dan NIM terhadap ROA. Hal ini dapat dilihat dari hasil yang menunjukkan nilai $F$ hitung sebesar 42,492 dengan $p$-value $=0,000<\alpha=0,05$.
\end{abstract}

Kata Kunci: CAR, LDR, NIM, ROA, Bursa Efek Indonesia

\begin{abstract}
This study aims to determine the effect of (CAR) towards (ROA), to determine the effect of (LDR) to (ROA), to determine the effect (NIM) to (ROA), and to determine the effect (CAR), (LDR), and (NIM) to (ROAin the national private foreign exchange bank as listed in the Indonesia Stock Exchange from 2015 to 2017. This study implements a causalquantitative research design. The subjects were National Private Foreign Exchange Banksthrough 2015-2017 period totaling 19 banks. The object of the research is financial statements which consist of various ratios of CAR, LDR, NIM and ROA during 20152017. The obtained data were collected using the method of documentation. The results of this study were there is an influence of CAR on ROA. It can be seen from the results that show the $t$ value of 2.108 with a $p$-value $=0.040<\alpha=0.05$. There is an influence of LDR on ROA. It can be seen from the results that show the t value of 2.829 with a $p$ value $=0.000<\alpha=0.05$. There is an influenceofNIM on ROA. It can be seen from the results that show the value of $t 2,200$ with $p$-value $=0.032<\alpha=0.05$. There is the influence of CAR, LDR, and NIM on ROA. It can be seen from the results that show the counts value of $F$ which equal to 42.492 with a $p$-value $=0.000<\alpha=0.05$.
\end{abstract}

Key words : CAR, LDR, NIM, ROA, Indonesian Stock Exchange 


\section{PENDAHULUAN}

Salah satu lembaga yang berperan penting dalam perekonomian suatu negara adalah bank. Berdasarkan Undang-Undang No. 10 Tahun 1998 Tentang Perbankan, bank memiliki fungsi utama, yaitu menghimpun dana dan menyalurkannya kembali ke masyarakat dalam bentuk kredit atau lainnya serta berperan dalam memberikan pelayanan dalam lalu lintas pembayaran dan peredaran uang. Hal ini menunjukkan bahwa kinerja perbankan di suatu negara berdampak besar bagi perekonomian. Krisis moneter tahun 1998 yang melanda Indonesia berdampak begitu besarnya sehingga banyak bank di Indonesia yang harus dilikuidasi. Menurut Pradjoto (2003), terhitung paling tidak terjadi likuidasi terhadap 16 bank, penggiringan 40 bank ke wilayah BPPN, pembekuan bank dan pengambilalihan bank. Berdasarkan hal tersebut, kesehatan dan ketahanan perbankan dalam menghadapi krisis menjadi fokus perhatian Bank Indonesia (BI) dan semenjak tanggal 31 Desember 2013 diambil alih oleh Otoritas Jasa Keuangan (OJK) sebagai pengawas perbankan Indonesia.

Bank dituntut untuk meningkatkan kinerjanya dalam persaingan bisnis yang semakin ketat agar dapat menarik investor.Informasi mengenai kinerja bank sangat penting untuk diketahui investor sebelum dananya diinvestasikan.Kinerja bank dapat diketahui dengan menggunakan analisis rasio. Menurut Kasmir (2012), analisis rasio merupakan analisis yang digunakan untuk mengetahui hubungan pos-pos antara laporan keuangan neraca dan laporan laba rugi. Jadi,salah satu rasio yang digunakan untuk mengetahui kinerja bank adalah laba atau profitabilitas.

Capital Adequacy Ratio (CAR) pada Rencana Bisnis Bank (RBB) menunjukkan bahwa realisasi Capital Adequacy Ratio (CAR) terhadap Rencana Bisnis Bank (RBB) belum tercapai maksimal sehingga menyebabkan belum tercapainya Return on Assets (ROA) yang maksimal. Menurut Sudiyatno dan Suroso (2010:127), Capital
Adequacy Ratio (CAR) adalah rasio kinerja bank untuk mengukur kecukupan modal yang dimiliki bank untuk menunjang aktiva yang mengandung atau menghasilkan risiko, misalnya kredit yang diberikan. Menurut Dendawijaya (2009:121), Capital Adequacy Ratio (CAR) adalah rasio yang memperhatikan seberapa jauh seluruh aktiva bank yang mengandung risiko ikut dibiayai dari dana modal sendiri bank disamping memperoleh dana-dana dari sumber-sumber diluar bank, seperti dana dari masyarakat, pinjaman dan lain-lain. Semakin besar Capital Adequacy Ratio (CAR) semakin besar kemampuan permodalan bank, sehingga banyak dana yang dapat dimanfaatkan oleh manajemen bank untuk meningkatkan pendapatan. Capital Adequacy Ratio (CAR) merupakan faktor yang penting sehingga semakin tinggi CAR mengindikasikan bahwa bank telahmempunyai modal yang baik dalam menunjang kebutuhannya, sehingga kenaikan rasio CAR akan diikuti oleh pemasukan laba yanglebih baik pula karena naiknya CAR membuat bank lebih leluasa dalam pengembangan usahanya dan lebih baik dalam menampung kemungkinan adanya risiko kerugian (Susilo, 2000: 58). Dengan meningkatnya pemasukan laba, maka ROA bank juga akan meningkat

Loan to Deposit Ratio (LDR) pada Rencana Bisnis Bank (RBB) menunjukkan bahwa realisasi Loan to Deposit Ratio (LDR) terhadap Rencana Bisnis Bank (RBB) belum tercapai maksimal sehingga menyebabkan belum tercapainya Return on Assets (ROA) yang maksimal. Menurut Simorangkir (2004: 147), Loan to Deposit Ratio merupakan perbandingan antarakredit yang diberikan dengan dana pihak ketiga. Menurut Dendawijaya (2009:116), Loan to Deposit Ratio atau rasio kredit dengan dana pihak ketiga adalah seluruh jumlah kredit yang diberikan bank dengan dana yang diterima oleh bank. Latumaerissa (2014: 96) mengemukakan bahwa, rasio LDR adalah rasio keuangan perusahaan perbankan yang berhubungan dengan aspek likuiditas.Rasio ini menggambarkan sejauh 
mana simpanan digunakan untuk pemberian pinjaman. Apabila tingkat rasio LDR semakin tinggi, maka semakin rendah tingkat likuiditas bank dan akan menyebabkan keuntungan bagi bank. Semakin tinggi LDR, maka laba bank semakin meningkat. Menurut Lubis (2017:2578), Loan to Deposit Ratio akan meningkatkan Return on Assets, sehingga kinerja keuangan bank akan semakin baik dengan asumsi bank tersebut mampu menyalurkan kredit dengan efektif sehingga jumlah kredit macetnya akan kecil. Hal ini menunjukkan bahwa Loan to Deposit Ratio berpengaruh positif terhadap Return on Assets.

Net Interest Margin (NIM) pada Rencana Bisnis Bank (RBB) menunjukkan bahwa realisasi Net Interest Margin (NIM) terhadap Rencana Bisnis Bank (RBB) belum tercapai maksimal sehingga menyebabkan belum tercapainya Return on Assets (ROA) yang maksimal. Net Interest Margin (NIM) merupakan rasio yang mengukur kemampuan bank dalam menghasilkan pendapatan bunga bersih dengan penempatan aktiva produktif (Taswan, 2009: 167). Menurut Mawardi (2005), Net Interest Margin (NIM) adalah selisih antara total biaya bunga pendanaan dengan total biaya bunga pinjaman. Dengan demikian, besarnya Net Interest Margin (NIM) akan mempengaruhi laba rugi Bank yang pada akhirnya mempengaruhi kinerja bank tersebut. Setiap peningkatan Net Interest Margin (NIM)akan mengakibatkan peningkatan Return on Assets (ROA), karena setiap peningkatan pendapatan bunga bersih, yang merupakan selisih antara total biaya bunga dengan total pendapatan bunga mengakibatkan bertambahnya laba sebelum pajak, yang pada akhirnya mengakibatkan peningkatan Return on Assets (ROA).

Realisasi Return on Assets (ROA) pada bank umum tahun 2015 belum tercapai maksimal. Pada kategori Buku 1, Return on Assets (ROA) pada Rencana Bisnis Bank (RBB) sebesar $1,83 \%$, namun yang tercapai sebesar $1,45 \%$. Selanjutnya, pada kategori Buku 2, Return on Assets (ROA) pada Rencana Bisnis Bank (RBB) sebesar 2,15\%, namun yang tercapai sebesar 1,43\%. Pada kategori Buku 3, Return on Assets (ROA) pada Rencana Bisnis Bank (RBB) sebesar $1,90 \%$, namun yang tercapai sebesar 1,44\%. Pada kategori Buku 4, Return on Assets (ROA) pada Rencana Bisnis Bank (RBB) sebesar $3,88 \%$, namun yang tercapai sebesar $3,50 \%$. Kemudian, pada kategori Industri, Return on Assets (ROA) pada Rencana Bisnis Bank (RBB) sebesar 2,44\%, namun yang tercapai sebesar $2,32 \%$. Data tersebut menunjukkan bahwa realisasi Return on Assets (ROA) terhadap Rencana Bisnis Bank (RBB) belum tercapai maksimal.

\section{METODE}

Penelitian ini menggunakan
rancangan kuantitatif kausal yang digunakan untuk memperoleh eksplanasi yang teruji mengenai pengaruh CAR, LDR, dan NIM terhadap ROA pada bank umum nasional devisa yang terdaftar di Bursa Efek Indonesia. Penelitian ini menggunakan dua jenis variabel, yaitu variabel dependen dan variabel independen yaitu, pertama Variabel dependen disebut juga variabel terikat, merupakan variabel yang dipengaruhi atau yang menjadi akibat karena adanya variabel bebas. Variabel dependen dalam penelitian ini adalah Return On Assets (Y), dan kedua Variabel independen disebut juga variabel bebas, merupakan variabel yang mempengaruhi atau yang menjadi sebab perubahannya atau timbulnya variabel terikat. Variabel independen dalam penelitian ini adalah Capital Adequacy Ratio $\left(\mathrm{X}_{1}\right)$, Loan to Deposit Ratio $\left(\mathrm{X}_{2}\right)$ dan Net Interest Margin $\left(\mathrm{X}_{3}\right)$.

Subjek dalam penelitian ini adalah Bank Umum Swastra Nasional Devisa yang terdaftar di Bursa Efek Indonesia (BEI) periode 2015-2017. Sedangkan, objek dalam penelitian ini adalah laporan keuangan yang terdiri dari ratio-ratio antara lain CAR, LDR, NIM dan ROA tahun 20152017. 
Jenis dan sumber data dalam penelitian ini, Jenis data dalam Penelitian ini menggunakan data kuantitatif. Data kuantitatif dalam penelitian ini berupa laporan keuangan yang terdiri dari ratioratio antara lain CAR, LDR, NIM dan ROA yang diperoleh dari situs resmi Bursa Efek Indonesia melalui www.idx.co.id dan www.sahamok.com. Sedangkan, sumber data dalam penelitian ini Penelitian ini menggunakan data sekunder. Data sekunder, yaitu sumber data yang diperoleh melalui media perantara atau secara tidak langsung, artinya data-data tersebut berupa dokumen yang telah di publikasi melalui situs www.idx.co.id dan www.sahamok.com. Sumber data dalam penelitian ini adalah laporan keuangan yang terdiri dari ratioratio antara lain CAR, LDR, NIM dan ROA pada Bank Umum Swastra Nasional Devisa yang terdaftar di Bursa Efek Indonesia (BEI) periode 2015-2017.

Metode pengumpulan data dalam penelitian ini ialah menggunakan Metode pengumpulan data yang dilakukan dalam penelitian ini adalah dengan menggunakan metode dokumentasi. Metode dokumentasi, merupakan metode pengumpulan data dengan mengumpulkan dokumen-dokumen melalui situs www.idx.co.id dan www.sahamok.com kemudian di print out dan dilakukan analisis. Dalam penelitian ini dokumen yang digunakan adalah Laporan Keuangan periode 2015-2017 untuk mengetahui ratio-ratio antara lain CAR, LDR, NIM dan ROA.

Teknik analisis data dalam penelitian ini menggunakan pertama Uji statistik yang meliputi: a) Uji t (pengujian secara parsial). Analisis ini digunakan untuk mengetahui pengaruh Capital Adequacy Ratio ( $\left.\mathrm{X}_{1}\right)$ terhadap Return On Assets ( $Y$ ), pengaruh Loan to Deposit Ratio $\left(\mathrm{X}_{2}\right)$ terhadap Return On Assets (Y), pengaruh Net Interest Margin $\left(\mathrm{X}_{3}\right)$ terhadap Return On Assets $(\mathrm{Y})$. Pengujian ini dilakukan dengan menggunakan significance level 0,05 $(\alpha=5 \%)$. Jika nilai signifikan $>0,05$ maka Ho ditolak (koefisien regresi tidak signifikan). Ini berarti bahwa secara parsial variabel independen tersebut tidak mempunyai pengaruh signifikan terhadap variabel dependen. Jika signifikan $<0,05$, maka Ho diterima (koefisien regresi signifikan). Ini berarti secara parsial variabel independen tersebut mempunyai pengaruh yang signifikan terhadap variabel dependen.. b) Uji $F$ (pengujian secara simultan). Analisis ini digunakan untuk mengetahui yaitu pengaruh Capital Adequacy Ratio $\left(\mathrm{X}_{1}\right)$, Loan to Deposit Ratio $\left(\mathrm{X}_{2}\right)$, dan Net Interest Margin $\left(\mathrm{X}_{3}\right)$ secara bersama-sama terhadap Return On Assets (Y) pada bank umum nasional devisa di bursa efek indonesia. Kedua, Uji Regresi Linier Berganda. Analisis regresi linier berganda digunakan untuk membuktikan apakah Capital Adequacy Ratio, Loan to Deposit Ratio, dan Net Interest Margin terdapat pengaruh terhadap Return On Assets pada bank umum nasional devisa di bursa efek Indonesia. Ketiga, Uji Asumsi Klasik yang meliputi: a) Uji Normalitas bertujuan untuk menguji apakah dalam model regresi, variabel pengganggu atau residual terdistribusi normal, b) Uji Multikolinearitas bertujuan untuk menguji apakah dalam model regresi ditemukan adanya korelasi antar variabel independen (Ghozali, 2011:105), c) Uji Heteroskedastisitas bertujuan untuk menguji apakah dalam model regresi terjadi ketidaksamaan variance dari residual satu pengamatan ke pengamatan yang lain (Ghozali 2011), dan d) Uji Autokorelasi. Autokorelasi sering dikenal denga nama korelasi serial dan sering ditemukan pada data serial waktu (time series). Uji autokorelasi bertujuan menguji apakah dalam model regresi ada korelasi antara kesalahan pengganggu pada periode $t$ dengan kesalahan pada periode $t-1$ (sebelumnya).

\section{HASIL DAN PEMBAHASAN Hasil Penelitian}

Hasil penelitian ini meliputi pertama, untuk mengetahui pengaruh CAR terhadap ROA pada Bank Umum Swasta Nasional Devisa yang terdaftar di Bursa Efek 
Indonesia Tahun 2015-2017. Kedua, untuk mengetahui pengaruh LDR terhadap ROA pada Bank Umum Swasta Nasional Devisa yang terdaftar di Bursa Efek Indonesia Tahun 2015-2017. Ketiga, untuk mengetahui pengaruh NIM terhadap ROA pada Bank Umum Swasta Nasional Devisa yang terdaftar di Bursa Efek Indonesia Tahun 2015-2017 dan keempat untuk mengetahui pengaruh CAR, LDR, dan NIM terhadap ROA pada Bank Umum Swasta Nasional Devisa yang terdaftar di Bursa Efek Indonesia Tahun 2015-2017.
Data yang pertama Pengaruh CAR terhadap ROA pada Bank Umum Swasta Nasional Devisa yang terdaftar di Bursa Efek Indonesia Tahun 2015-2017. Untuk mengetahui pengaruh CAR terhadap ROA, dilakukan analisis test dengan menggunakan program SPSS 16.0 for windows. Hasil analisis tersebut menunjukkan bahwa pengaruh CAR terhadap ROA pada Bank Umum Swasta Nasional Devisa yang terdaftar di Bursa Efek Indonesia dapat dilihat pada tabel 1.

Tabel 1. Hasil Uji t pengaruh Capital Adequacy Ratio terhadap Return on Assets Tahun 20152017

Coefficients $^{\mathrm{a}}$

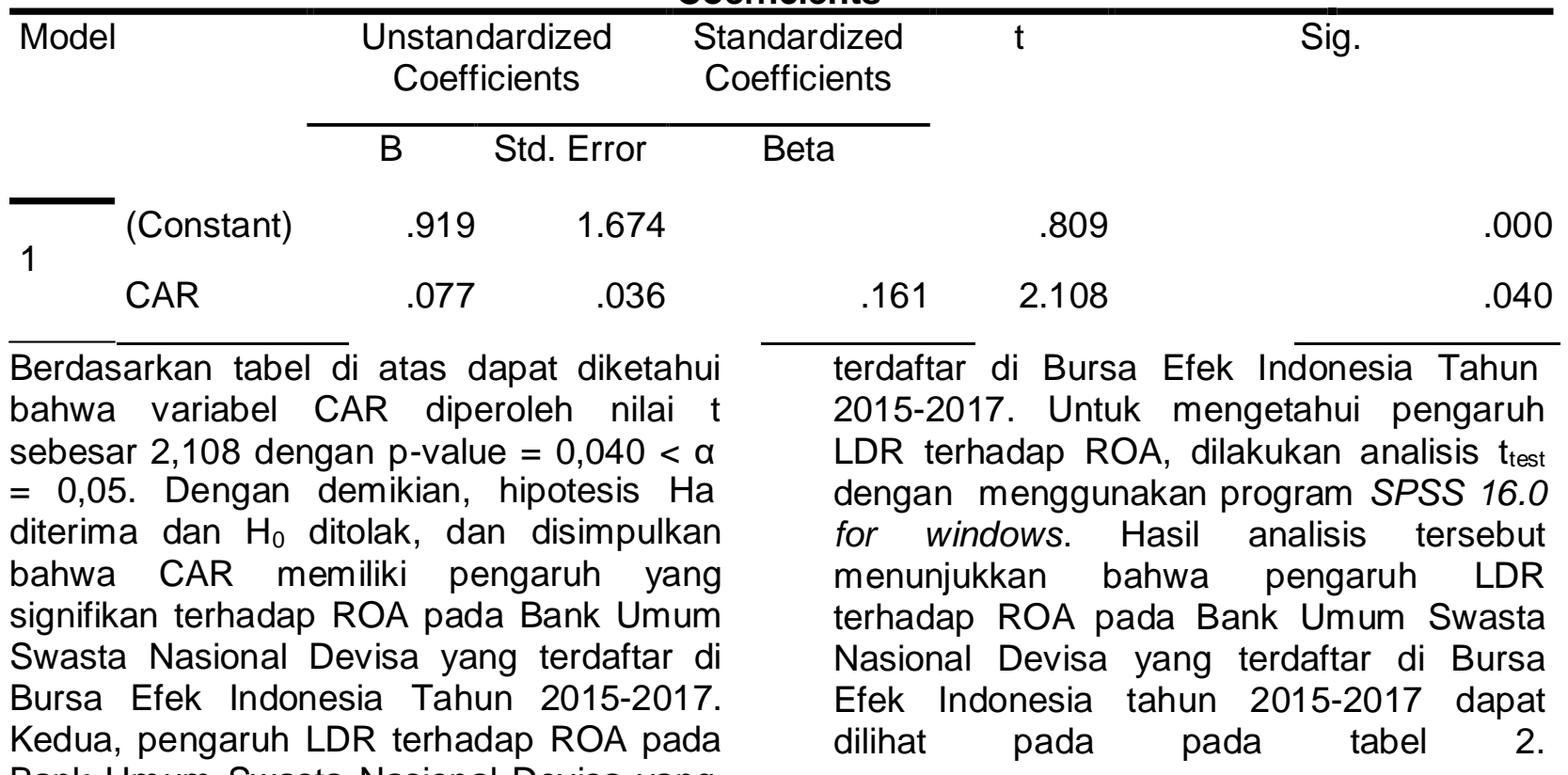

Tabel 2. Hasil Uji t pengaruh Loan to Deposit Ratio terhadap Return on Assets Tahun 20152017

\section{Coefficients $^{\mathrm{a}}$}

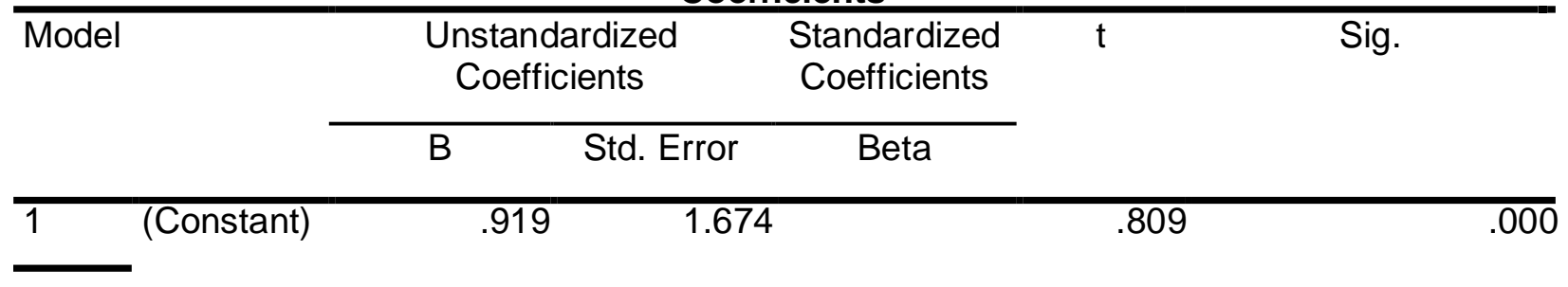




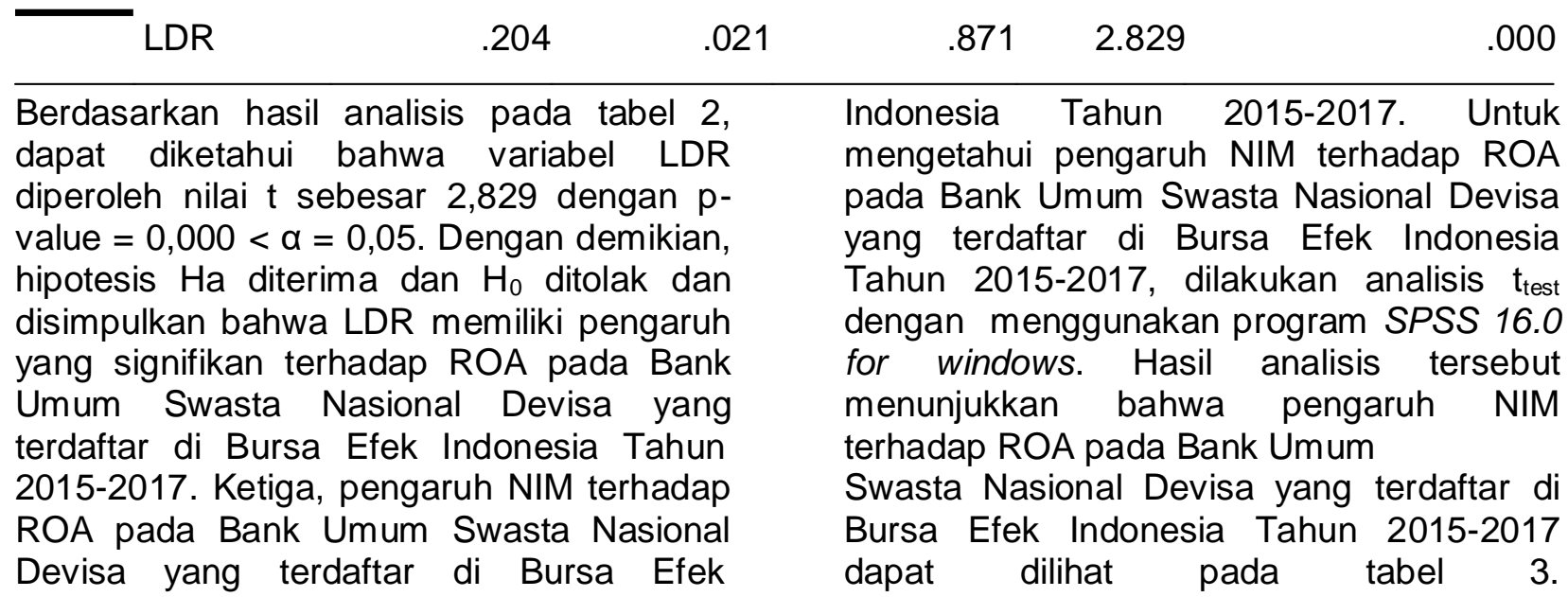

Tabel 3. Hasil Uji t Pengaruh Net Interest Margin terhadap Return on Assets Tahun 2015-2017 Coefficients $^{a}$

\begin{tabular}{lrrrrrr}
\hline Model & \multicolumn{2}{c}{$\begin{array}{c}\text { Unstandardized } \\
\text { Coefficients }\end{array}$} & $\begin{array}{c}\text { Standardized } \\
\text { Coefficients }\end{array}$ & t & Sig. \\
\cline { 3 - 5 } & B & \multicolumn{2}{c}{ Std. Error } & Beta & & \\
\hline 1 & (Constant) & .919 & 1.674 & & .809 & .000 \\
NIM & .115 & .052 & .191 & 2.200 & .032
\end{tabular}

Berdasarkan hasil analisis pada tabel 3, dapat diketahui bahwa variabel NIM diperoleh nilai $t$ sebesar 2,200 dengan $p$ value $=0,032<\alpha=0,05$. Dengan demikian, hipotesis $\mathrm{Ha}$ diterima dan $\mathrm{H}_{0}$ ditolak dan disimpulkan bahwa NIM memiliki pengaruh yang signifikan terhadap ROA pada Bank Umum Swasta Nasional Devisa yang terdaftar di Bursa Efek Indonesia Tahun 2015-2017, dan keempat, pengaruh CAR, LDR, dan NIM terhadap ROA pada Bank Umum Swasta Nasional Devisa yang terdaftar di Bursa Efek Indonesia Tahun
2015-2017. Untuk mengetahui pengaruh secara simultan CAR, LDR, dan NIM terhadap ROA pada Bank Umum Swasta Nasional Devisa yang terdaftar di Bursa Efek Indonesia Tahun 2015-2017 dilakukan dengan menggunakan uji statistik $F$ dengan program SPSS 16.0 for windows. Hasil analisis tersebut menunjukkan bahwa adanya pengaruh yang signifikan $\operatorname{CAR}\left(\mathrm{X}_{1}\right)$, $\operatorname{LDR}\left(\mathrm{X}_{2}\right)$ dan NIM $\left(\mathrm{X}_{3}\right)$ terhadap ROA $(\mathrm{Y})$. Hasil uji statistik $F$ tersebut dapat dilihat pada

Tabel 4. Hasil Uji Statistik Simultan (Uji F) pengaruh Capital Adequacy Ratio $\left(\mathrm{X}_{1}\right)$, Loan to Deposit Ratio $\left(\mathrm{X}_{2}\right)$ dan Net Interest Margin $\left(\mathrm{X}_{3}\right)$ terhadap Return on Assets $(\mathrm{Y})$ Tahun 2015-

\section{7}

ANOVA $^{\mathrm{a}}$

Model
Sum of
Squares df
Mean

Square
Sig. 


$\begin{array}{llccccc} & \text { Regression } & 38.798 & 3 & 12.933 & 42.492 & .000^{\text {a }} \\ 1 & \text { Residual } & 16.131 & 53 & .304 & & \\ \text { Total } & 54.929 & 56 & & & \end{array}$

Berdasarkan hasil analisis uji statsistik $F$ pada tabel 4, diperoleh nilai $F$ hitung sebesar 42,492 dengan $p$-value $=0,000<\alpha$ $=0,05$. Hal ini berarti bahwa secara simultan CAR, LDR, dan NIM berpengaruh signifikan terhadap ROA pada Bank Umum Swasta Nasional Devisa yang terdaftar di Bursa Efek Indonesia Tahun 2015-2017. Untuk mengetahui besarnya pengaruh
Capital Adequacy Ratio, Loan to Deposit Ratio, dan Net Interest Margin terhadap Return on Assets pada Bank Umum Swasta Nasional Devisa yang terdaftar di Bursa Efek Indonesia Tahun 2015-2017 dapat diketahui melalui hasil analisis koefisien determinasi (Adjust $R$ Square). Adapun hasil analisis koefisien determinasi (Adjust $R$ Square) dapat dilihat pada tabel 5.

Tabel 5. Hasil analisis koefisien determinasi (Adjust $R$ Square)

Model Summary ${ }^{\mathrm{b}}$

\begin{tabular}{|c|c|c|c|c|c|}
\hline Model & $\mathrm{R}$ & R Square & $\begin{array}{l}\mathrm{d} R \\
\mathrm{re}\end{array}$ & $\begin{array}{l}\text { Std. Error of } \\
\text { the Estimate }\end{array}$ & $\begin{array}{l}\text { Durbin- } \\
\text { Watson }\end{array}$ \\
\hline 1 & & & & & \\
\hline \multicolumn{3}{|c|}{$\begin{array}{l}\text { Pada tabel } 5 \text { memperlihatkan hasil analisis } \\
\text { koefisien determinasi (Adjust } R \text { Square). } \\
\text { Nilai koefisien determinasi (Adjust } R \\
\text { Square) sebesar 0,690 atau 69\%, hal ini } \\
\text { berartiReturn on Assetssebesar } 69 \% \\
\text { dipengaruhi oleh Capital Adequacy Ratio, } \\
\text { Loan to Deposit Ratio, dan Net Interest } \\
\text { Margin, sedangkan sisanya sebesar } 31 \%\end{array}$} & \multicolumn{3}{|c|}{$\begin{array}{l}\text { Berdasarkan pengolahan data yano } \\
\text { digunakan untuk mengetahui persamaar } \\
\text { garis regresi, pengaruh CAR, LDR, dan NIN } \\
\text { terhadap ROA pada Bank Umum Swasta } \\
\text { Nasional Devisa yang terdaftar di Burse } \\
\text { Efek Indonesia digunakan analisis koefisier } \\
\text { beta. Besarnya koefisien beta yaitu dapa } \\
\text { dilihat pada tabel } 6\end{array}$} \\
\hline
\end{tabular}
dipengaruhi oleh faktor lain yang tidak diteliti dalam penelitian ini.

Tabel 6. Hasil Perhitungan Koefisien Beta.

Coefficients $^{a}$

\begin{tabular}{|c|c|c|c|c|c|}
\hline \multirow[t]{2}{*}{$\overline{\text { Model }}$} & \multicolumn{2}{|c|}{ Unstandardized Coefficients } & $\begin{array}{l}\text { Standardized } \\
\text { Coefficients }\end{array}$ & \multirow[t]{2}{*}{$\bar{T}$} & \multirow[t]{2}{*}{ Sig. } \\
\hline & $B$ & Std. Error & $\overline{\text { Beta }}$ & & \\
\hline (Constant) & .919 & 1.674 & & .809 & .000 \\
\hline CAR & .077 & .036 & .161 & 2.108 & .040 \\
\hline LDR & .204 & .021 & .871 & 2.829 & .000 \\
\hline
\end{tabular}


Berdasarkan hasil analisis pada tabel 6, dengan mengunakan program SPSS 16.0 for windows dapat dibuat persamaan garis regresi. Persamaan garis regresi yang dapat dibuat untuk menggambarkan pengaruh Capital Adequacy Ratio, Loan to Deposit Ratio, dan Net Interest Margin terhadap Return on Assets pada Bank Umum Swasta Nasional Devisa yang terdaftar di Bursa Efek Indonesia Tahun 2015-2017 adalah sebagai berikut.

$$
\begin{aligned}
\hat{Y}=0,919+ & 0,077 X_{1}+0,204 X_{2}+ \\
0,115 X_{3} & +\varepsilon \\
\text { Keterangan: } & \\
\hat{Y} & =\text { Return on Assets } \\
\alpha & =\text { konstanta } \\
X_{1} & =\text { Capital Adequacy Ratio } \\
X_{2} & =\text { Loan to Deposit Ratio } \\
X_{3} & =\text { Net Interest Margin } \\
\varepsilon & =\text { Error Estimate }
\end{aligned}
$$

Persamaan garis regresi tersebut mengartikan bahwa pada saat nilai $X_{1}$ $(C A R), \mathrm{X}_{2}(L D R)$ dan $\mathrm{X}_{3}(N I M)$, bernilai 0 atau konstan, maka nilai $\mathrm{Y}(R O A)$ sebesar 0,919 . Setiap ada kenaikan variabel bebas $\mathrm{X}_{1}(C A R), \mathrm{X}_{2}(L D R)$ dan $\mathrm{X}_{3}$ (NIM), sebesar satu satuan maka akan meningkatkan $Y$ $(R O A)$ sebesar nilai koefisien beta masingmasing variabel bebas dikalikan dengan besarnya kenaikan yang terjadi. Misalnya, setiap terjadi kenaikan $X_{1}$ (Capital Adequacy Ratio) sebesar satu satuan, maka akan meningkatkan $\mathrm{Y}$ (Return on Assets) sebesar 0,077 atau $7,7 \%$, setiap terjadi kenaikan $\mathrm{X}_{2}$ (Loan to Deposit Ratio) sebesar satu satuan, maka akan meningkatkan Y (Return on Assets) sebesar 0,204 atau $20,4 \%$ dan setiap terjadi kenaikan $\mathrm{X}_{3}$ (Net Interst Margin) sebesar satu satuan, maka akan meningkatkan $Y$ (Return on Assets) sebesar 0,115 atau $11,5 \%$. Hal ini berarti, semakin tinggi Capital Adequacy Ratio, Loan to Deposit Ratio, dan Net Interest Margin maka semakin besar pengaruhnya terhadap Return on Assets pada Bank Umum Swasta Nasional Devisa yang terdaftar di Bursa Efek Indonesia Tahun 2015-2017, sebaliknya semakin rendah Capital Adequacy Ratio, Loan to Deposit Ratio, dan Net Interest Margin tersebut maka semakin rendah Return on Assets pada Bank Umum Swasta Nasional Devisa yang terdaftar di Bursa Efek Indonesia Tahun 2015-2017.

\section{Pembahasan}

Salah satu lembaga yang berperan penting dalam perekonomian suatu negara adalah bank, bank memiliki fungsi utama, yaitu menghimpun dana dan menyalurkannya kembali ke masyarakat dalam bentuk kredit atau lainnya serta berperan dalam memberikan pelayanan dalam lalu lintas pembayaran dan peredaran uang. Dalam pembahasan ini akan dipaparkan temuan-temuan yakni, pertama pengaruh Capital Adequacy Ratio terhadap Return on Assets pada Bank Umum Swasta Nasional Devisa yang terdaftar di Bursa Efek Indonesia Tahun 2015-2017. Hal ini sejalan dengan penelitian yang dilakukan oleh Ahmad Buyung Nusantara (2009) dengan hasil penelitian CAR berpengaruh positif signifikan terhadap ROA. Hasil analisis data dalam penelitian ini menunjukkan bahwa Capital Adequacy Ratio memiliki pengaruh yang signifikan terhadap Return on Assets pada Bank Umum Swasta Nasional Devisa yang terdaftar di Bursa Efek Indonesia Tahun 2015-2017. Jika CAR tinggi, kepercayaan masyarakat terhadap bank tersebut akan semakin besar. Dengan demikian dapat disimpulkan bahwa Capital Adequacy Ratio (CAR) merupakan rasio kinerja bank untuk mengukur kecukupan modal yang dimiliki bank untuk menunjang aktiva yang mengandung atau menghasilkan risiko. Hasil penelitian ini didukung oleh teori yang dikemukan oleh Susilo (2000: 58), Capital Adequacy Ratio (CAR) merupakan faktor yang penting sehingga semakin tinggi CAR 
mengindikasikan bahwa bank telah mempunyai modal yang baik dalam menunjang kebutuhannya, sehingga kenaikan rasio CAR akan diikuti oleh pemasukan laba yang lebih baik pula karena naiknya CAR membuat bank lebih leluasa dalam pengembangan usahanya dan lebih baik dalam menampung kemungkinan adanya risiko kerugian. Kedua pengaruh Loan to Deposit Ratio terhadap Return on Assets pada Bank Umum Swasta Nasional Devisa yang terdaftar di Bursa Efek Indonesia Tahun 2015-2017. Hasil analisis data dalam penelitian ini menunjukkan bahwa Loan to Deposit Ratio memiliki pengaruh yang signifikan terhadap Return on Assets pada Bank Umum Swasta Nasional Devisa yang terdaftar di Bursa Efek Indonesia Tahun 2015-2017. Rasio LDR digunakan untuk mengukur kemampuan bank tersebut apakah mampu membayar utang-utangnya dan membayar kembali kepada deposannya, serta dapat memenuhi permintaan kredit yang diajukan. Dengan kata lain, seberapa jauh pemberian kredit kepada nasabah, kredit dapat mengimbangi kewajiban bank untuk segera memenuhi permintaan deposan yang ingin menarik kembali uangnya yang telah digunakan oleh bank untuk memberikan kredit (Dendawijaya, 2003: 118). Hasil penelitian ini didukung oleh teori yang dikemukan oleh Lubis (2017: 2578), Loan to Deposit Ratio akan meningkatkan Return on Assets, sehingga kinerja keuangan bank akan semakin baik dengan asumsi bank tersebut mampu menyalurkan kredit dengan efektif sehingga jumlah kredit macetnya akan kecil. Hal ini menunjukkan bahwa Loan to Deposit Ratio berpengaruh positif terhadap Return on Assets. Ketiga pengaruh Net Interest Margin terhadap Return on Assets pada Bank Umum Swasta Nasional Devisa yang terdaftar di Bursa Efek Indonesia Tahun 2015-2017. Hasil analisis data dalam penelitian ini menunjukkan bahwa Net Interest Margin memiliki pengaruh yang signifikan terhadap Return on Assets pada Bank Umum Swasta Nasional Devisa yang terdaftar di Bursa Efek Indonesia Tahun 2015-2017. Net Interest Margin (NIM) merupakan rasio yang menunjukkan kemampuan manajemen bank dalam mengelola aktiva produktifnya untuk menghasilkan pendapatan bunga bersih. Pendapatan bunga bersih diperoleh dari pemberian kredit atau pinjaman, sementara bank memiliki kewajiban beban bunga kepada deposan. Hasil penelitian ini didukung oleh teori yang dikemukan oleh Mawardi (2005), Net Interest Margin (NIM) adalah selisih antara total biaya bunga pendanaan dengan total biaya bunga pinjaman. Dengan demikian, besarnya Net Interest Margin (NIM) akan mempengaruhi laba rugi Bank yang pada akhirnya mempengaruhi kinerja bank tersebut. Setiap peningkatan Net Interest Margin (NIM) akan mengakibatkan peningkatan Return on Assets (ROA), karena setiap peningkatan pendapatan bunga bersih, yang merupakan selisih antara total biaya bunga dengan total pendapatan bunga mengakibatkan bertambahnya laba sebelum pajak, yang pada akhirnya mengakibatkan peningkatan Return on Assets (ROA), keempat pengaruh Capital Adequacy Ratio, Loan to Deposit Ratio, dan Net Interest Margin terhadap Return on Assets pada Bank Umum Swasta Nasional Devisa yang terdaftar di Bursa Efek Indonesia Tahun 2015-2017. Hasil analisis data dalam penelitian ini menunjukkan bahwa Capital Adequacy Ratio, Loan to Deposit Ratio, dan Net Interest Margin memiliki pengaruh yang signifikan terhadap Return on Assets pada Bank Umum Swasta Nasional Devisa yang terdaftar di Bursa Efek Indonesia Tahun 2015-2017, yang ditunjukkan dengan nilai uji $F_{\text {hitung }}$ sebesar 42,492 dengan $p$-value = $0,000<\alpha=0,05$. Hal ini sejalan dengan penelitian yang dilakukan oleh Millatina (2011), yang menyatakan bahwa semakin besar Capital Adequacy Ratio (CAR) dan Net Interest Margin (NIM) suatu bank, maka semakin besar pula profitabilitas bank tersebut, yang berarti kinerja keuangan tersebut semakin meningkat dan Pandu Mahardian (2008) dengan hasil penelitian 
CAR, LDR dan NIM berpengaruh positif signifikan terhadap ROA. Kelima, besarnya Pengaruh Capital Adequacy Ratio, Loan to Deposit Ratio, dan Net Interest Margin terhadap Return on Assets pada Bank Umum Swasta Nasional Devisa yang terdaftar di Bursa Efek Indonesia Tahun 2015-2017 dapat diketahui melalui hasil analisis koefisien determinasi (Adjust $R$ Square) sebesar 0,690 atau $69 \%$ dan sisanya sebesar $31 \%$ dipengaruhi oleh faktor lain yang tidak diteliti dalam penelitian ini.

\section{SIMPULAN DAN SARAN}

Berdasarkan hasil penelitian dan pembahasan hipotesis terkait dengan pengaruh Capital Adequacy Ratio, Loan to Deposit Ratio, dan Net Interest Margin terhadap Return on Assets pada Bank Umum Swasta Nasional Devisa yang terdaftar di Bursa Efek Indonesia Tahun 2015-2017, maka dapat disimpulkan Ada pengaruh Capital Adequacy Ratio terhadap Return on Assets pada Bank Umum Swasta Nasional Devisa yang terdaftar di Bursa Efek Indonesia Tahun 2015-2017, yang ditunjukan dengan nilai uji t sebesar 1.428 dengan $p$-value $0.003<\alpha=0,05$ yang artinya terdapat pengaruh positif antara Capital Adequacy Ratio terhadap Return on Assets. Ada pengaruh Loan to Deposit Ratio terhadap Return on Assets pada Bank Umum Swasta Nasional Devisa yang terdaftar di Bursa Efek Indonesia Tahun 2015-2017, yang ditunjukan dengan nilai uji t sebesar 1.704 dengan $p$-value $0.004<\alpha=$ 0,05 yang artinya terdapat pengaruh positif antara Loan to Deposit Ratio terhadap Return on Assets. Ada pengaruh Net Interest Margin terhadap Return on Assets pada Bank Umum Swasta Nasional Devisa yang terdaftar di Bursa Efek Indonesia Tahun 2015-2017, yang ditunjukan dengan nilai uji $t$ sebesar 4.325 dengan $p$-value $0.000<\alpha=0,05$ yang artinya terdapat pengaruh positif antara Net Interest Margin terhadap Return on Assets. Ada pengaruh Capital Adequacy Ratio, Loan to Deposit Ratio, dan Net Interest Margin terhadap
Return on Assets pada Bank Umum Swasta Nasional Devisa yang terdaftar di Bursa Efek Indonesia Tahun 2015-2017, yang ditunjukan dengan nilai $f$ hitung 8.459 dengan p-value $0.000<\alpha=0,05$ yang artinya secara simultan terdapat pengaruh positif antara Capital Adequacy Ratio, Loan to Deposit Ratio, dan Net Interest Margin terhadap Return on Assets. Besarnya Pengaruh Capital Adequacy Ratio, Loan to Deposit Ratio, dan Net Interest Margin terhadap Return on Assets pada Bank Umum Swasta Nasional Devisa yang terdaftar di Bursa Efek Indonesia Tahun 2015-2017 dapat diketahui melalui hasil analisis koefisien determinasi (Adjust $R$ Square) sebesar 0,690 atau $69 \%$, hal ini berartiReturn on Assetssebesar 69\% dipengaruhi oleh Capital Adequacy Ratio, Loan to Deposit Ratio, dan Net Interest Margin, sedangkan sisanya sebesar 31\% dipengaruhi oleh faktor lain yang tidak diteliti dalam penelitian ini.

Berdasarkan pemaparan mengenai hasil penelitian dan simpulan, terdapat dua saran yang dapat disampaikan dalam penelitian ini. Pertama, bagi Bank Umum Swasta Nasional Devisa disarankan mempertimbangkan Loan to Deposit Ratio karena paling besar pengaruhnya dibandingkan variabel lain untuk meningkatkan Return on Assets pada Bank Umum Swasta Nasional Devisa. Hal ini diharapkan dapat menghasilkan laba bagi bank dengan cara menyalurkan lebih banyak kredit kepada nasabah. Kedua, bagi peneliti lain, penelitian ini masih sederhana. Oleh karena itu, peneliti lain diharapkan mengembangkan penelitian sejenis dengan variabel yang lain.

\section{DAFTAR PUSTAKA}

Ahmad Buyung Nusantara. (2009). "Analisis Pengaruh NPL, CAR, LDR, dan BOPO Terhadap Profitabilitas Bank" (Perbandingan Bank Umum Go Publik dan Bank Umum Non Go Publik di Indonesia Periode Tahun 2005-2007). Tesis. Universitas Diponegoro 
Dendawijaya, Lukman. 2003. Manajemen Perbankan. Ghalia Indonesia. Jakarta

Dendawijaya, Lukman. 2009. Manajemen Perbankan Edisi Kedua. Jakarta: Ghalia

Ghozali, Imam. 2011. Aplikasi Analisis Multivariate dengan Program IBM SPSS 19 Cetakan V. Semarang: Badan Penerbit Universitas Diponegoro

Kasmir. 2012. Bank dan Lembaga Keuangan Lainnya. Jakarta: PT Raja Grafindo Persada.

Latumaerissa, Julius R. 2014. Manajemen Bank Umum. Jakarta: Mitra Wacana

Lubis, Fadhiah Annisa. 2017. Pengaruh Loan To Deposit Ratio (LDR), Non Performing Loan (NPL), Capital Adequacy Ratio (CAR), Net Interest Margin (NIM), Biaya Operasional Pendapatan Operasional (BOPO) terhadap Return On Asset (Studi Kasus pada Perusahaan Perbankan yang Terdaftar di Bursa Efek Indonesia Tahun 2012-2015). eProceeding of Management, Vol.4, No. 3, Hal: 2575-2584

Mahardian, Pandu. (2008). Analisis Pengaruh Ratio CAR, BOPO, NPL, NIM, dan LDR terhadap Kinerja Keuangan Perbankan (studi kasus pada perusahaan Perbankan yang tercatat di BEJ periode juni 20022007). Skripsi. Semarang : FE Universitas Diponegoro
Mawardi, Wisnu. 2005. Analisis FaktorFaktor yang Mempengaruhi Kinerja Keuangan Bank Umum di Indonesia (Studi Kasus pada Bank Umum dengan Total Aset Kurang dari 1 Triliun). Jurnal Bisnis dan Strategi.Vol. 14.No. 1. Juli 2005

Millatina Arimi dan Mohammad Kholiq Mahfud. 2012. Analisis FaktorFaktor yang Mempengaruhi Profitabilitas Perbankan (Studi Pada Bank Umum yang Listed di Bursa Efek Indonesia Tahun 2007-2010). Diponegoro Journal of Management

Pradjoto. 2003. Mencegah Kebangkrutan Bangsa: Pelajaran dari Krisis (Kumpulan Tulisan Pradjoto dan Catatan Para Sahabat). Jakarta: Masyarakat Transparansi Indonesia.

Simorangkir. 2004. Pengantar Lembaga Keuangan Bank dan Non Bank. Jakarta : Ghalia Indonesia

Sudiyatno dan Suroso. 2010. Analisis Pengaruh Dana Pihak Ketiga, BOPO, CAR, dan LDR terhadap Kinerja Keuangan Pada Sektor Perbankan yang Go Public di Bursa Efek Indonesia (BEI) periode 20052008. Hal: 125-137

Susilo. 1999. Bank dan Lembaga Keuangan Lain, Cetakan Pertama, Salemba Empat, Jakarta

Taswan. 2009. Manajemen Lembaga Keuangan Mikro BPR. Semarang: Badan Penerbit Fakultas Ekonomi Universitas Stikubank 